\title{
Problematizing home, belonging and identity in Bina Sharif's My Ancestor's House: a transnational approach
}

\author{
Nesrin Yavaş ${ }^{1}$ \\ 1 Assist. Prof. Dr., Ege University, Faculty of Literature, Department of American Culture and Literature, İzmir, TURKEY, E-mail: nesrinyavas@yahoo.com
}

\begin{abstract}
Since the 1990s, transnationalism, a as recent field of enquiry, has emerged as another theoretical lens through which we can look into the changing, evolving meanings of home, homeland, and belonging for international migrants. Studies of transnational migrants have focused upon varying aspects of the migrants' lives: their ties with their kin; laws of naturalization in the host country, involvement in political organizations, the place of cultural iconography such as food, music, tradition in their daily lives. Because these transmigrants neither cut the ties to their countries of origin nor fully assimilate into the new culture of the host country, these immigrants fall under the rubric of transnationals However, transnational studies focusing upon the cross-border lives and activities of transnational subjects ignore the cross-cutting variables of gender, class, age, religion, ideology, period of immigration, citizenship status, different local sending contexts, which play a mediatory role in shaping notions of home, identity, community within even a single transnational community. In order words, it is not possible to talk about the transnationalism of a certain migrant group but of the heterogeneous make-up of transnationalisms, which differ even among the members of a transnational community at any given point in time. To understand the relationship between transnational migrants, and their conceptions of home and belonging, it is of vital importance to explore the specific circumstances of migration and how they influence conceptions of home. Secondly, the celebratory overtones of the transnational conditions of international migrants overlook the negative consequences of transnational lives such as the feelings of loss and dislocation inherent in cross border movements of transmigrants. Reading Pakistani-American Bina Sharif's play My Ancestor's House through a transnational lens, I would argue, brings a new insight into the literature on transnationalism by way of highlighting the non-homogenous, non-celebratory, and historically specific aspects of transnationalism in a global age.
\end{abstract}

Keywords: Transnationalism, Transmigrant, Migration, Home/Homeland, Identity, Belonging, Trans-Locality, Globalization 


\section{INTRODUCTION}

"My emotional strength and my structure weakened when I crossed the ocean and separated myself from my homeland, from my loved ones, from my parents, my brothers and sisters, from my seasons, my spice, my language, from the fallen leaves in Autumn and long narrow muddy paths lined with daffodils and roses." Bina Sharif

Bina Sharif is a Pakistani-born American playwright, who immigrated to the United States to escape from the oppressive Islamic regime of her homeplace and to realize her dream of becoming an artist in the United States. In the introductory notes to her play My Ancestor's House, Bina Sharif explains (qtd. Perkins and Uno, 1996: 262) that it was not only her artistic inclinations but also her search for freedom, liberty, equality, and justice which brought her to the United States. My Ancestor's House is a memory play, in which Bina Sharif not only attempts to come to terms with her feelings of quilt and shame for having left her family behind but also delineates the contours of her migrant identity.

This paper seeks to challenge the assumption that transnational subjects find their home in the movement across national and cultural borders. Homi Bhabba's conception of hybridity, Stuart Hall's conception of diasporic hybrid identities, James Clifford's homophone roots/routes, all fall short of explaining the transnational migrant Bindia in My Ancestor's House. For Homi Bhabba (1994:9) hybridity is not a matter of celebration but the prevailing mode of being in the world that undermine essentialized, monolithic notions of nation, authenticity, tradition and culture: "It is that Third Space, though unrepresentable in itself, which constitutes the discursive conditions of enunciation that ensure that the meanings and symbols of cultures have no primordial unity and fixity; that even the same signs can be appropriated, translated, rehistoricized, and read anew." In other words, this Third Space is the liminal, the in-between position of becoming, which undermines static notions of home and identity. This means that home for transnational migrants straddling across borders is not tied to a specific geographical place but to a state of mind which continuously evolves, shifts, and is transformed with shifting circumstances. Viewed this way, the transnational migrant moves back and forth between their homeplace and host country both culturally and / or geographically, engaging in constant (re)negotiations of their multiple identities, in our case Americanness and Pakistani identity. Therefore, according to Homi Bhabba, "To be unhomed is not to be homeless" (1994, 9).

Stuart Hall (1990) approaches the concept of home critically, arguing for its creative and dynamic potentials. For Hall (1990), the concept of home is neither static nor fixed, but it is one of transformation and hybridity:

The diaspora experience as I intend it here is defined not by essence or purity, but by the recognition of a necessary heterogeneity and diversity; by a conception of identity which lives with and through, not despite, difference; by hybridity. Diaspora identities are those which are constantly producing and reproducing themselves anew, through transformation and difference. (235)

Arjun Appadurai's (1996) celebratory attitude towards this constant motion of goods, cultures, people, ideas across borders in the globalizing world and his lack of attention to the role of the nation-states means that for Appadurai (1996) in today's world global transnational communities have replaced nationstates. As a recent field of enquiry, transnationalism has emerged as another theoretical lens through which we can look into the changing, evolving meanings of home for international migrants. Since its emergence in the 1990s, the literature on the transnational practices of migrants has shed light upon individuals and families: "how ordinary individuals live their everyday lives across borders and the consequences of their activities for sending-and receiving country life" (Lewitt and Waters 2002:8). Michael Smith and Luis Guernizo (1998) have defined this relationship between transnationalism and migrants' everyday lives as "transnationalism from below" in contrast to transnational activities that occur in such areas as the media, political institutions, financial organizations, and transnational businesses, namely "transnationalism from above." The transnational framework can delineate the importance of the webs of linkages between home and host countries. Basch, Glick Schiller and Blanc (1995) contend that many migrants are now transmigrants, "whose daily lives depend on multiple and constant interconnections across international borders and whose public identities are configured in relationship to more than one nation-state" (48). Because these transmigrants neither cut the ties to their countries of origin nor fully assimilate into the new culture of the host country, these immigrants fall under the rubric of transnationals. Links to the home country are maintained 
Studies of transnational migrants have focused upon varying aspects of the migrants' lives: their ties with their kin; laws of naturalization in the host country, involvement in political organizations, the place of cultural iconography such as food, music, tradition in their daily lives. Lately, the importance of the national and international policy making processes have been deemed to be central to an understanding of transnational activities (Levitt, De Wind \& Vervotec 2003: 568). However, transnational studies focusing upon the cross-border lives and activities of transnational subjects ignore the cross-cutting variables of gender, class, age, religion, ideology, period of immigration, citizenship status, different local sending contexts, which play a mediatory role in shaping notions of home, identity, community within even a single transnational community. In order words, it is not possible to talk about the transnationalism of a certain migrant group but of the heterogeneous make-up of transnationalisms, which differ even among the members of a transnational community at any given point in time. Therefore, it becomes all the more important to shy away from traditional homogeneous conceptualizations of transnationalism, and to see into the specificities of circumstances which generate different conceptions of home and belonging. In addition, the general consensus on the situation of the transnational migrants as subjects constructing their lives and their identities in unbounded and ungrounded spaces across borders does nothing but to essentialize the multiplicity of the tactics transmigrants deploy to set boundaries and to establish ground identities.

Transnationalism has different meanings for different people at different times of their lives. To understand the relationship between transnational migrants, and their conceptions of home and belonging, it is of vital importance to explore the specific circumstances of migration and how they influence conceptions of home. The celebratory overtones of the transnational conditions of international migrants overlook the negative consequences of transnational lives such as feelings of loss and dislocation inherent in cross border movements of transmigrants.

\section{ENTERING MY ANCESTOR' HOUSE THROUGH THE DOOR OF TRANSNATIONALISM}

Reading Bina Sharif's (1996) My Ancestor's House through a transnational lens yields new insights into the scholarship on transnationalism as well as into the concepts of home and belonging. Understanding the protagonist Bindia's transnationalism in the play first and foremost necessitates to evaluate the social, political and cultural contexts of the sending country, in our case 1980s Pakistan. As Jigna Desai (2004) argues the nation-state constitutes a very important variable in the globalized world of international migration. The leading scholars of transnationalism agree upon the fact that nation states play a central role in creating and maintaining transnational lives (Guernizo \& Smith 1998; Ong 1999; Smith 1998) Transformations, changes in the country of origin as well as in the receiving countries impact the migrants' transnational activities through which they articulate conceptions of home and belonging. In the case at hand, Bindia has left her family and her homeland Pakistan years ago to flee from Zia ul Haq's Islamic, oppressive regime, which curbed individual liberties in all walks of life. Bindia is a Muslim Pakistani woman, who must realize her gender roles according to the dictates of the traditional, social and familial codes: filiality, arranged marriages, kinship responsibilities, following the religious codes of Islam. Under these circumstances, the specific context of opportunities and constrains gain considerable significance (Guarnizo \& Smith 1998:13). Bindia flees Pakistan's specific context of oppression to the United States' specific context of liberty, freedom, and equality.

In the States, Bindia is free from the dictates of her religion as well as her social and familial responsibilities. She marries an American actor, which is unacceptable according to the Pakistani religious and social regulatory norms. The restrictions and confinements of the sending country find their best expression in the words of Roona, one of Bindia's sisters, who remained behind: "Our religion, our parents, our Qur'an, our men had weakened our soul" (Sharif, 1996:269). Husain Haggani (2010:144) states how the Islamization of all state institutions left Pakistani women vulnerable both in the domestic and the public sphere: Pakistani women were strictly banned from participating in sports and arts; according to the sharia law, a man's legal testimony equaled to the testimonies of two women; with the Hudood Ordinance, thousands of rape victims were incarcerated on charges of zina. The victim's failure to her allegation at court was understood to be a confession of extra-marital relationship, namely, zina (Siam-Heng and Liew 2010:360). Apart from the sharia law, the traditional codes of the the society dictate that women have to prepare a splendiferous dowry to be entitled to marriage and strictly follow their parents' choices and decisions in the name of filiality. 
Deedi, the little sister, has been cast out of the family circle for marrying a man out of her choice rather than following the traditional marriage patterns. In fact, Deedi's marrying outside an arranged marriage is taken as a big blow against the family name and reputation in the community. Deedi has to pay for behaving outside the established moral and social codes: She is left all alone with an unloving, abusing and good for nothing of a husband. Bindia's rage against Pakistan's gendered traditions that leave no outlet for individual freedom for women like Deedi and Roona is echoed in her words: "if this kind of situation happened in America ... to an American woman, man she would kick his ass in a minute" (Sharif, 1996:269). However, for Deedi there is no such option in a society ruled with sharia law and fixed traditional codes of

Bindia visits Pakistan because her mother is sick in hospital but the reunion with her family makes her feel more like a foreigner in the face of familial confrontations and accusations. Resentment over her stay in a foreign country, and envy on the part of those who weren't brave enough to leave, accusations for not coming back and taking care of her sick mother, all make Bindia feel like "as if I have no right to take any space anywhere" (Sharif ,1996: 269). Bindia's dislocation both in her homeland and her hostland leaves her with a permanent feeling of being out of place. When Nazo says to Bindia that Pakistan is her home and explains her confusion over Bindia's self-willed exile in a foreign land, Roona interferes and exclaims how insecure and groundless she feels in her homeland. This vignette between three sisters reveals different notions of home and belonging: For Nazo, home is Pakistan, where one must confirm his / her rootedness through social and cultural habits and rituals. Roona's conception of home is not a placerelated one. Rather, her home is where she could be a liberated woman with a mind of her own, disentangled from all structures of oppression. When Roona says that she would rather be an exile in the United States rather than be a ghost-like presence, an absence with no agency in her homeland, Bindia reveals her sense of alienation and dislocation in the United States as follows:

(...) I wanted to follow a straight path and could not handle the turns. I got lost somehow. I have a personal weakness. In my heart of hearts, I wanted to destroy myself. People over there were different but they wanted me to be part of them. I kept feeling too small ... too little . . like nobody . . . I kept missing home. My heart kept shrinking with some kind of unknown fear of losing something.
Not belonging anywhere My heart was not there. It was here ... in the country yards ... in the jasmine trees ... I kept looking back-I couldn't go forward. My soul got weaker and weaker. I wandered around aimlessly in the gloomy streets of my new home, which I could not call a home. Maybe I never wanted a home. (Sharif, 1996: 271-272)

Despite feeling like an outsider in her host country, Bindia never considers return migration: "But I never established myself in America. And all the pressure from back home ... the pull ... 'come home' . . 'come back'. The more I suffered here, the less I wanted to come back (. . .)" (Sharif, 1996: 270). Bindia has chosen not to live in Pakistan "as a spinster ... as a good, obedient daughter, a Muslim spinster. . (Sharif, 1966: 269) but her new "home" with all its freedom and modernity has not given her a sense of belonging either. She admits that she wanted to cut off all the ties that link her to Pakistan but that she failed: (. . .) I crossed the ocean ... I wanted to cut the cord ... the cord ... stretched, and stretched across the Atlantic like a strong nylon that never breaks ... distance was so long . . . it stretched. . . and stretched . . . soon it will get tangled ... soon it will suffocate me. (Sharif, 1966: 269)

Bindia's feelings of guilt for having abandoned her loved ones, for not taking care of her lonely mother, for not having been able to save her sister Deedi from the desperate life she has been forced to live as a result of her independent manners accompany her all the way to the United States. A family history inflicted with traumas has always haunted her in her new life in the host country, which gave her freedom but never a "home." Bindia's family history prevents her from setting her heart at ease about being in the United States. The harsh criticisms she has had to face each time she visits her family together with Pakistan's unstable political situation and despotic religious regime also alienates Bindia to her birthplace. In this sense, Bindia never belongs. Home for Bindia is always elusive.

Apart from the political and social instabilities in the homeland, the meanings attached to Bindia's migrancy by those who stayed behind constitute an important variable that impacts Bindia's transnationalism and the developmental options available to her. Bindia's family expected her to make the best of herself by completing her medical education in the US and to become a doctor, which Bindia never realized. A non-achiever in the United States, Bindia's situation is unacceptable in a relatively well-to-do Pakistani family. Bindia's 
abandonment of her family must be compensated by stories of success in the US, which she has never achieved. It is apparent that the disillusionment on the part of those who stayed behind has been a recurring theme during Bindia's temporary stays in Pakistan, which finds expression in the words of Nazo:

NAZO: But you must make a lot of money? You live in America. Don't you make a lot of money? Last time you came us you told us you had a great job.

\section{BINDIA: No! I don't.}

NAZO: You must make more money than us . . . one dollar is equal to fifteen rupees . . . so . . . whatever you make... you make fifteen time more money than me!

NAZO: If you don't make a lot of money, which is not belivable, why do you live there? (Sharif, 1996: 267-268)

As important as those who move are, those who stay put have just as much influence on transnational processes. In the sending context, in our case Pakistan, "people go abroad to achieve something" (Sharif, 1996:268) but Bindia has "[a]bandoned a highly respectable profession, left her home, made herself isolated for no good reason" (Sharif, 1996:268). This is unacceptable.

What further complicates Bindia's situation as a transmigrant is the apparent lack of the flow of goods, and remittances across national borders. P. Werbner (1989) in her study of Pakistanis in Great Britain highlights the importance of gift exchange and remittances in the maintenance of socioeconomic and sociocultural relations across borders. Werbner (1988) states that " $[w]$ hile gifts and exchange are key to the social networks in Britain, they are also a 'metonymic' exchange of substance between South Asia and Britain" (204). Helen Lee and Steve Tupai Frances (2009) in their study on Pacific migration and transnationalism argue that "[p]articular goods express notions about the places from which they come. (...) Goods (. . .) carry ideas about power which are exchanged between [the home country] and overseas" (66). H. Lee and S.T. Tupai (2009) cast light on the importance of the exchange of goods such as videos, Tv sets, DVDs, electronic goods, carrying with them symbolic messages from the host country: "economic power, industrial production and popular Western culture" (66). In My Ancestor's House (Sharif, 1996), for those who stayed behind remittances and gifts that travel across borders are symbols of-the migrant's generosity and hard work, core social values by which Bindia is evaluated. Because Bindia's transnational life as a Pakistani living in the United States never complies with her family's conception of an acceptable overseas life, on her every visit to Pakistan, Bindia ismade to feel ashamed of herself for "not buying bungalows, and cars, for not sending [her siblings' children] toys, for not bringing VCRs and diamond rings ..." (Sharif, 1966:269).

The members of Bindia's immediate family except Roona attempt to domesticate her differences such as her Americanized dress code and smoking right from her point of entry into the social and cultural circles of Pakistani life. Even the servant Ali Buksh, just because he is a man, feels entitled to tame her American modernity, which never complies with the moral and traditional codes of Pakistan. To be content with what Allah gives, to accept one's Kismet, that is, your fate, are, Ali Buksh the servant explains, the cardinal virtues of a good Pakistani Muslim woman (Sharif, 1996:265-266). America is a "kafir country, wild country" (Sharif, 1966: 265), says Ali Buksh;therefore, it is no place for a Pakistani Muslim woman. Apparently, in the home country individual belonging depends on a willingness to submit to the pressures of cultural and social conformity. Non-conformity means being cast out of your family as well as the society. Bindia's difference is entirely defined by Roona, the eldest sister, and Ali Buksh by juxtaposing her foreignness with the principles of duty and conformity that are passed down through family and tradition. For Roona and Ali Buksh, Bindia is the Other of the family by virtue of her Americanized outlook as well as her nonconformity to tradition. Instead of coming back and taking care of her ailing mother, who, as Roona says to Bindia, has been missing Bindia year in and year out, Bindia has not assumed this role dictated by tradition.

In the case of Bindia, being a Pakistani woman emerges as a field of complex re-negotiations within the country of origin, which, opens up no new, alternative avenues for self-identification as a transnational migrant. Pakistan is no home for Bindia because the "ancestor's house", in the words of Eva Hoffman (1999:58), "is a conservative site of enclosure, of narrow-mindedness, patriarchal attitudes, and dissemination of nationalism," a fact which is also expressed by Roona when she exclaims, "I feel like I have always been on an exiled land" (Sharif, 1996: 269). Unable to demand a divorce in a Muslim country ruled by Sharia and having no hope in the future of her three daughters in a country like Pakistan, Roona feels insecure and lost 
in her "homeplace". That's why she says to Bindia, "You are better off in America. Even if it is hard there. Bindia, trust me it is much harder here. And American society . . . must be so free, and different. So open. Just to be able to breathe. You could do anything you want. Be anything you want" (Sharif, 1996: 271). For both Roona and Bindia, leaving means liberation, whereas staying connotes crippling. Through the character of Roona, Bina Sharif further complicates notions of home and belonging: for Roona, home is not a fixed geographical place but a sense of security and safety. Such conception of home resonates with Biddy Martin and Chandra Talpade Mohanty's (1998) distinguishing between two forms of feeling related to home, "being home" and "not being home," which refer to different experiences of home either as providing safety or repressing one's identity (19). In other words, the link between the notion of home and a geographical homeland is severed, and the fixed, essentialized definitions of identity and belonging in terms of a place-based definition of home are problematized.

Then what is home for Bindia, who has chosen to leave rather than stay in her birthplace? Answering this question first and foremost necessitates to reappropriate Homi Bhabba's theory of Third Space, Stuart Hall's conception of diasporic hybrid identity and James Clifford's roots/routes homophone within the historical and cultural specificities of Bindia's transnationalism, and then to proceed to an understanding of Bindia's transnationalism as shaped by specific sending and receiving contexts, which in turn shapes her sense of belonging and identity.

To begin with, for Homi Bhabba "to be unhomed is not to be homeless" (1994:9) because home has become the very movement across two or more national borders. Bhabba does not valorize this Third Space hybridity but he affirms that this is the primary mode of being in a highly globalized world. In the case of Bindia, however, "to be unhomed" is to "be homeless". The cord that stretches across continents represents her roots in Pakistan, and she can never get rid of the shackles of her past in the host country. Bindia cannot carve out new meanings of home and belonging while journeying both physically and imaginatively across borders.

Stuart Hall's understanding of diasporic hybridity also fails to account for Bindia's homesickness. For Stuart Hall (1990) the experiences of in-betweenness and mobility can transform from the sense of not- being-home to a more positive experience generating hybridity. Hyphenated identities, as John McLeod argues, "are perpetually in motion, pursuing errant and unpredictable routes, open to change and reinscription" (2000: 219). John McLeod's (2000) "unpredictable roots" immediately recalls James Clifford (1992,1997) and Paul Gilroy's (1993) use of the homophone roots/routes to define two different negotiations of cultural identity in their theorizations of intercultural mixing and migratory identities: "Roots" refers to notions of common origin, homogeneous understandings of culture and tradition whereas "routes" imply forms of intercultural movement and migration. If we define Bindia's "roots" as Pakistan, and her "routes" as her migration to the States, the ensuing journeys across borders, her refusal to comply with the inhibitive and oppressive structures of thought and behaviour of her homeland, then, Bindia's routes never offer the discovery of something new. In the words of Andrew Smith (2004) Bindia's in-betweenness does not offer "epiphanies: new insight, new knowledge, and a new understanding of the relativity of things" (257) with which she could have carved out more flexible meanings of home and belonging.

\section{CONCLUSION}

Viewed from a transnational lens, Bindia is a transmigrant straddling borders across nation states, Pakistan and the United States. However, Bindia's transnationalism undermines many essentialist, and heterogeneous approaches in the literature on transnationals. Indeed, as becomes apparent in the discussion above, Bindia cannot easily fit into the theoretical pigeonholes of transnationalism. First, Bindia's transnationalism has negative rather than positive outcomes. Her dislocation in and alienation to both the United States and Pakistan counterbalance a tendency in the earlier transnational literature to celebrate transnationalism as a means to boost "innovative energy" (Bhabba, 1994: 324315), by means of which the transnational subjects could enhance their social networks and manage the problems they experience in the host country. In this context, Bindia's transnationalism has afforded her none of the opportunities. Secondly, Bindia's transnationalism undermines Arjun Appadurai's (2004:15) demise of the nation-states in favor of transnational communities. Both the receiving and the sending contexts in My Ancestor's House (Sharif, 1996) impact the options available to Bindia to engage in transnational activities. Bindia has left Zia Ul Haq's oppressive Islamic regime for the individual liberties 
and freedom the United States offers. Moreover, Bindia never considers return to Pakistan despite the fact that she has never felt at home in her host country. Bindia had to leave her Muslim homeland and come to the United States to be labeled as a "Muslim woman". She runs away from all the fixed systems of tradition and religion in Pakistan only to be labelled as the Muslim other in the United States. Therefore, Bindia's transnationalism can only be understood within specific historical, political conjectures. Additionally, Bindia's transnationalism underscores the heterogeneity found within each of the transnational migrant due to the cross-cutting cleavages of class, gender, religion, and tradition, thereby it suggests an anti-essentialist approach for transnational studies. Finally, Bindia is an atypical transmigrant in that remittances and exchanges of goods and gifts have never been a part of her transnational life, which is considered to be an important aspect of the daily lives of transmigrants who have ties to two or more countries. We understand that Bindia returns on a regular basis feeling compelled due to circumstances, for example elderly parents, a sick family member, death in the family, or property issues. Bindia's motivation for engagement in transnational fields and practices should be sought in the specific circumstances of being a Pakistani migrant in the United States in the 1980s. As Nadje AlAli and Khalid Koser (2002:5) aptly argue, there is a need to move beyond the homogenizing tendencies of transnational studies:

All too often migrant and refugee communities are homogenized and presented in an undifferentiated manner (...) migrants might seek transnational ties with their countries because of nationalist sentiments, political motivations and in search of prestige and increased status (...) In some cases, transnational activities and engagements are more a result of social pressure, unwelcome family responsibilities an even feelings of guilt. These factors demand a more critical appraisal of transnationalism, away from simplistic notions of transnationalism as being empowering and liberating.

Bindia's transnational ties with her country of origin are determined by her feelings of guilt, which, in fact, make her transnational engagements across borders context-specific. Her feelings of guilt for having left her kin and family behind, for becoming the Other of the family rather than their pride, for having tainted the so-called family reputation by marrying an American actor, for not returning "home" and taking care of her sick mother, for not having pursued her medicine education in the States, which her deceased father had always dreamed of. However, Bindia's each return to her "homeland" not only further intensifies her feelings of guilt but also her alineation to her culture, her people, her kin, and her family. In other words, each temporary return to the "homeland" ensures her return to the United States, which she defines as "not home". Therefore, Bindia's ongoing connections are also disconnections.

Bindia's transnationalism is accompanied by loss and dislocation; she does not feel "at home" in any one place, which provokes in turn an identity crisis leading to a continuous sense of being unsettled. Transnational links, in the case of Bindia do not have the power of overthrowing the rupture emanating from the ultimate sense of homelessness. Analysed from this perspective, transnationalism and the ongoing movements in My Ancestor's House (Sharif, 1996) do not seem simply to reconcile fractures but to intensify insecurities and anxieties. It is one of my intentions to show in this study how Bina Sharif in her play My Ancestor's House, by thematizing movement and migrancy, questions not only alleged stability of identity but also the celebration of physical and/ or cultural movements of transmigrants across nation-state borders as a liberating and empowering condition. Concomitantly, notions of home and homeland become problematic in the play. The family plays the role of the nation. In other words, Bindia's family is a microcosm of 1980s Pakistan with all its traditional taboos, suppression of individual liberties, intolerance, cultural and religious dogmatism. Fixed codes of gender, religion, nation, tradition, and family "form lines of stratification and coordinates with a specific place and function and draw the outer boundary line of the community's logic of incluson and exclusion" (Moslund, 2010: 103). The overarching machinery of fixity and conformity is thus reinscribed into the history of Bindia's family ridden with disruptions and breaches in family relations. Therefore, Bina Sharif's representation of home reveals a succession of traumatic experiences enacted within the home and the history of the family. The idealized notion of home as a site of harmony seems to be a fantasy; home transforms into a space where the traumas of a nation are inseparable from the traumas of a family. Avtar Brah's (1996: 193) concept of "homing desire", or rather homing desires, I would argue, best encapsulates Bindia's conception home as a transnational migrant: the harmony of home is only accessible in Bindia's memories of the past, not in reality: 
BINDIA. Remember our jasmine filled courtyard (. . .) father with his hookah pipe (. . .) the tea (. ..) us laughing all night (. . .) But we would just giggle and giggle and talk all night and tell each other stories.

We had hopes and dreams, we had no sorrow, we had no pain, we had no shame. (Sharif, 1996: 270)

To conclude, home, from the perspective of cultural studies, can offer a sense of place and security but it can also function as the site of narratives of trauma and oppression (Mohanty \& Martin, 1988). Therefore, home in My Ancestor's House (Sharif, 1996) is not linked with some mythical geographical homeland. Bindia's future-oriented dream, "Maybe one day I will be able to get everybody in America and we will all be together like the old days. The good days" (Sharif, 1996: 270) also makes it clear that Bindia's home is not to be found in her ancestor's house but in imaginary dream-like spaces where she, together with her family, feel secure and safe from the uncertainties of the world. Bindia's home lies in her wishing of herself and her family away from Pakistan to an imagined life where she will be free from the shackles of tradition, nation, and history, both familial and national.

\section{REFERENCES}

- AL-ALI, NADJE \& KHALID KOSER (eds). (2002), New Approaches to Migration? Transnational communities and the transformation of home. London and New York: Routledge.

- APPADURAI, A. (1996). Modernity at Large: Cultural Dimensions of Globalization. Minneapolis: University of Minnesota Press.

- BASCH, L., N. GLICK SCHILLER \& C. SZANTON BLANC (1995), Nations Unbound: Transnational projects, postcolonial predicaments, and deterritorialized nation-states. New York: Gordon and Breach.

- BHABBA, H. (1994). The Location of Culture. London: Routledge.

- BRAH, A. (1996). Cartographies of Diaspora, London: Routledge.

- CLIFFORD, J. (1992). “Travelling Cultures"”" in L. Grossberg, C.Nelson, and P. Treichler (eds.)

Cultural Studies, London: Routledge, pp.96-111.

- CLIFFORD, J. (1997). Routes. Travel and Translation in the Late Twentieth Century. Cambridge,MA: Harvard University Press.

- DESAI, J. (2004). Beyond Bollywood: The Cultural Politics of South Asian Diasporic Film, London: Routledge.

- GILROY, P. (1993). The Black Atlantic: Modernity and Double Consciousness, Cambridge, MA: Harvard University Press.

- GUARNIZO, L.E. \& SMITH, M. P. (eds) (1998), Transnationalism from Below. New Brunswick: Transaction Publishers.

- HagGani, H. (2010). Pakistan. Between Mosque and Military. Washington, D.C.: Carnegie Endowment for International Peace.
- HALL, S. (1990), “Cultural Identity and Diaspora” in Rutherford, J. (ed.) Identity: Community, Culture, Difference, London: Lawrence and Wishart, pp.222-237.

- HALL, S. (1995), "New Cultures for Old" in D. Massey and P. Jess (eds.) A Place in the World? Places, Cultures, and Globalization, Oxford: Oxford University Press, pp. 175-213.

- LEWITT, P. \& M. WATERS (2002), Introduction in P. Lewitt and M. Waters (eds.) The Changing Face of Home: The Transnational Lives of the Second Generation, New York: Russell Sage Foundation, pp.130.

- LEVITT, P., J. DE WIND, \& S. VERVOTEC (2003), International Perspectives on Transnational Migration: An Introduction. International Migration Review (37)3 pp.565-75.

- MARTIN, BIDDY \& CHANDRA TALPADE MOHANTY (1988), "Feminist Politics: What's Home Got to Do with it?" in de Lauretis, Teresa (ed.) Feminist Studies/Critical Studies London: MacMillan, 191-211.

- McLEOD, J. (2007), “'Between Two Waves': Caryl Phillips and Black Britain in Moving Worlds". A Journal of Transcultural Writing 7(1):9-19.

- MOSLUND, S.T. (2010). Migration Literature and Hybridity. The Different Speeds of Transcultural Changes England: Palgrave MacMillan.

- ONG, A. (1999). Flexible Citizenship: The Cultural Logics of Transnationality, Durham, NC: Duke University Press.

- PERKINS, K.A. \& UNO, R. (eds). (1996). Contemporary Plays by Women of Color. An Anthology. London, New York: Routledge

- SHARIF, B. (1996). My Ancestor's House in Kathy A. Perkins and Roberto Uno (eds.) Contemporary Plays by Women of Color. An Anthology. London, New York: Routledge, pp.262-279.

- SIAM-HENG, MICHAEL HENG, \& TEN CHIN LIEW. (eds). (2010), State and Secularism: Perspectives from Asia. Singapore: World Scientific.

- SMITH, A. (2004). "Migrancy, Hybridity, and Postcolonial Literary Studies" in Nel Lazarus (ed.) The Cambridge Companion to Postcolonial Literary Studies. Cambridge: Cambridge University Press, pp.241-61.

- SMITH, R.C. (1998). Transnational Localities: Community, Technology, and The Politics of Membership within the Context of Mexico and US Migration" in M. P. Smith and L. E. Guernizo (eds) Transnationalism from Below, New Brunswick, NJ: Transaction Publishers, pp.196-238

- WERBNER, P. (1989). The Migration Process: Capital, gifts and offerings among British Pakistanis. Explorations in Anthropology Series, Oxford: Berg. 